\title{
ATTITUDES OF ENGLISH SPEAKERS TOWARDS THANKING IN SPANISH
}

\author{
Carlos de Pablos-Ortega
}

\begin{abstract}
The aim of this paper is to ascertain the attitudes English native speakers have towards the Spanish language and culture, specifically, in relation to the speech act of thanking and in connection with Brown and Levinson's model of politeness ([1978] 1987). Two sources of data were used: First, a corpus of 64 course books which included 250 situations representing the speech act of thanking and, second, a questionnaire for the teaching of Spanish as a Foreign Language. The situations including the speech act of thanking were analysed and then categorized according to various criteria. The criteria were created by taking into consideration Coulmas' (1981) proposal for the classification of thanking as well as the components of this specific speech act. The most frequent situations found in the course books were then used to devise the second source of data. The aim of this was to determine the attitudes of 300 participants, divided equally between the nationalities used in the investigation, Spanish, British and American. The questionnaire included 12 scenarios in which the thanking formula was omitted. Participants were prompted to answer questions based on their perceptions and to include other responses whenever they considered them to be appropriate. The main findings provided evidence of different facework values across the three groups of informants for some of the specific scenarios. Both quantitative and qualitative analyses of data showed that some of the responses were connected to the thanking formulae, but others to speech acts such as request formulae.
\end{abstract}

Keywords: Sociopragmatic; Speech Acts; Thanking; Attitude; Spanish; Politeness; Pragmalinguistic; Sociolinguistics.

\section{Introduction.}

When learning a foreign language, it appears that we tend to focus on elements directly related to aspects of a grammatical or lexical nature. However, there are other elements of equal importance such as how to greet people in a specific language or how to make requests in direct or indirect ways; we are referring here to the pragmatic components of a language.

While instructing learners of a foreign language it is essential to bear in mind all the sociocultural components of a language. On occasion, the materials used do not represent accurately the way in which native speakers interact in that specific language. As a consequence, learners might misinterpret certain cultural elements which are part of the target language.

The principles upon which the linguistic phenomenon of politeness is based differ from language to language and, as a consequence, misunderstandings may arise when non-native speakers come into contact with a specific language. This type of 
misunderstanding may refer to either particular linguistic structures used to express a type of communicative function, such as asking, or may refer to the norms and social elements that are an integral part of a specific culture. According to (Thomas 1983: 91), the first type of misunderstanding is termed pragmalinguistic failure, whereas the second is termed socio-pragmatic failure.

The fact that there are differences between languages in relation to the sociocultural norms and to the linguistic components and elements used to express a specific function in language, may give rise to and develop certain attitudes in the learners of a foreign language.

Therefore, teachers of foreign languages need to be aware of the presence of the pragmalinguistic and sociopragmatic components of a language in order to facilitate the development of the pragmatic competence of the foreign language learner. Consequently, the aim is to educate speakers to become competent not only from a linguistic, but also from an intercultural point of view.

Thanking is a speech act specific to each culture as it is not carried out in the same way in different communicative situations. Hymes (1971) points out that in most English-speaking cultures thanking can take place regardless of the situation. For example, if an offering or a promise is accepted or rejected by a speaker, thanking is used simply as recognition of that offering or promise. By contrast, in other cultures, in this case the Spanish culture, certain types of action do not require the use of thanking.

The research is concerned with three main aspects: Pragmatic features of communication, particularly those aspects related to the social usage that speakers make of their language (sociopragmatics) in relation to the linguistic phenomenon of politeness. Secondly, it is concerned with socio-linguistics features, particularly the speakers' attitudes towards the realisation of the speech act of thanking. Finally, this research is also relevant to applied linguistic issues, in particular to the resources and didactic strategies for the teaching of Spanish as a foreign language.

In this paper, we first provide a background to the investigations carried out up to the present day in relation to the speech act of thanking. Next, the methodological issues of the investigation are detailed and, finally, the most relevant findings are discussed as well as the implications of these results in the area of applied linguistics to the teaching of Spanish as a foreign language.

\section{Background to the research}

Thanking is a speech act which can be realised in various ways. According to Watts (2003), this speech act is part of the language that includes respectful forms, whilst, for Eleen (2001), expressing thanks is part of what is considered expressive politeness, related to polite language. Following Leech's classification (1983) this speech act can be categorized within what is known as absolute politeness, as an action supported by politeness. It is a speech act that also reinforces positive politeness, and as such, contributes to the harmonious development of social relationships between members of a community.

As for Brown and Levinson's ([1978] 1987) model of politeness, thanking can be categorised as a face threatening act for the receiver. Searle (1976) and Haverkate (1994) consider thanking as an expressive speech act which gives us information about 
the speaker's psychological state and, according to Escandell's (1996) conversational principles, thanking can also be included in what she calls social norms.

For Haverkate (2003: 66-67) the speech act of thanking fulfills the same function in both Spanish and Dutch cultures. It shows a difference in the sense that, in the Spanish culture, this speech act is not used as a routine answer in certain interactions (waiter-client, ticket inspector-passenger and seller-buyer). In these types of social intercourse, Spanish speakers tend to adopt a more rational attitude and do not usually thank. However, Dutch speakers tend to mark verbally the social distance that separates them from the interlocutor by thanking following these routine actions. As a consequence, some misunderstandings and intercultural conflicts might occur. It is not unusual for Dutch people to consider impolite the absence of thanking answers, which is normal in Spanish culture. To Spanish native speakers, the verbal reaction preferred in the Dutch culture (i.e. thanking) appears exaggerated, hypocritical or insincere.

In Spanish culture, polite formulae, like Please and Thank you, tend to be used literally, i.e. to ask or give thanks for a personal favour, as opposed to a rendered service which is part of someone's job, like the duty of a seller to assist people and the duty of clients when paying for what they have bought (Hickey 1991: 4).

Brown and Levinson ([1978] 1987: 245) distinguish between positive-politeness cultures and negative-politeness cultures. In positive-politeness cultures 'impositions' are 'small', 'social distance' is not an 'insuperable boundary to easy going interaction' and 'relative power' is 'never very great'. Whereas, in negative-politeness cultures there is 'social distance, asymmetry, and resentment of impositions'.

According to Watts (2003: 168-169) thanking can be taken as an institutional expression and can be categorized into semi-formulaic expressions and formulaic expressions. Formulaic ritualized utterances are 'highly conventionalised utterances, containing linguistic expressions which are used in ritualised forms of verbal interaction and have been reduced from fully grammatical structures to the status of extra-sentential markers of politic behaviour'. One example of these formulaic ritualised utterances is the speech act of thanking (very many thanks, thank you, thank you very much indeed). Watts points out that if these formulaic utterances are missing at the expected place in a conversation, the participant is seen as impolite, inconsiderate or rude.

Kerbrat-Orecchini (2004: 49) questions the absence of thanks as something impolite. She considers that this absence is not more impolite for non-native speakers than for native speakers of a specific language. In this case, as native speakers, we project our own norms to non-native speakers of that language. Aijmer (1996: 70) also points out that 'even small favours may result in profuse gratitude depending on the speakers' perception of the extra linguistic situations'. When thanking, we should take into consideration the object of thanking and the size of the favour, or some other extra linguistic factors, like the gender and age of the participants. Thanking is also required on certain social occasions, for example, some cultures understand that guests thank the host for a meal when they leave, or it is polite to praise the hosts' food whilst eating or thanking for hospitality at the end of a visit. From the discourse distribution point of view, Dumitrescu (2005: 377) indicates that thanking is a dyadic speech act, in the sense that it is usually followed by a verbal reaction, what is called an asymmetric adjacency pair.

We can therefore classify the speech act of thanking as an expressive act whose realization is determined by another act, previously performed by the interlocutor. The effect of this act (either verbal or non verbal) will benefit the speaker who thanked in 
the first instance. In many cultures it is also polite to inform the person who is thanking that it is not necessary to redress the balance. The researcher that tries to verify this hypothesis should take into account the fact that the speech act of thanking doesn't happen in all cultures in the same situations. The specific cultural features of thanking in Spanish and English make the English learners of Spanish feel that there is some degree of impoliteness when they learn Spanish. The consequence is that the perceived impoliteness brings a negative attitude towards the culture in the FL, and can have an impact on their learning process.

Until now, most of the research on the speech act of thanking has focused on linguistic issues more than on perceptions and interpretations made by both native and non native speakers of a language. Therefore, thanking has been analysed taking into consideration the way in which this specific speech act is performed and its relationship with other speech acts within the same language (Coulmas 1981; Kumantoridani 1999; Aijmer 1996). In other studies, the realization of the speech act of thanking is analysed when it is performed by native and non-native speakers of a language (Eisenstein and Bodman 1986; Dumitrescu 2005; and Hickey 2005). Other researchers have explored the differences of thanking between English and other languages: English-Italian (Aston 1995), English-Japanese (Ferrara 1994) and English-Spanish (Díaz 2003).

Coulmas (1981) was the pioneer of the research on thanking and his study on the area of contrastive pragmatics presents a two-fold objective. He analysed the speech acts of thanking and apologizing in Japanese in order to study the similarities between these speech acts. His study is the starting point for much of the research carried out by many other Japanese researchers (Kumatoridani 1999; Kim 1994; Kimura 1994; Miyake 1994; Moriyama 1999; Nakata 1989; Ogawa 1995)

Aijmer (1996) used the London-Lund Corpus of Spoken English in order to explore thanking, apologies, requests and offers in native speakers of English, whilst Jacobsson (2002) used the Corpus of English Dialogues to investigate thanking and the expressions associated with it from a historical perspective (from the sixteenth to the eighteenth centuries). Eisenstein and Bodman (1986) collected some data from native and non-native speakers of English so that they could determine how both groups express gratitude in some specific situations. They analysed how the production of the thanking formulae by learners of English as a foreign language differed from the thanking norms used by native speakers of English. Using Eisenstein and Bodman's study as a platform, Dumitrescu (2005) compared the pragmatic competence of native speaker students and non-native of speakers of Spanish in California (United States). Her main objectives were to find out the habitual strategies to express and react to gratitude in Spanish and to compare the strategies used by non-native speakers and by bilingual speakers in similar situations.

Hickey (2005) carried out some research on thanking in Spanish. He focused on a specific type of interaction: Present giving. He wonders whether, in this language there is 'a way of thanking [that] counts as giving thanks without admitting, even implicitly, that any debt has been incurred or that any balance needs to be redressed without acknowledging or presupposing that the hearer has done anything for the speaker's benefit' (Hickey 2005: 328). Aston (1995) found the use of thanking as a conversational closing signal by native speakers of both English and Italian, whilst Colston (2002) focused on the use of thanking expressions with non literal meanings. Ferrara (1994) carried out an ethnographic observation of fifteen non-native English speakers whose second language was Japanese in order to show the pragmatic transfer 
in the American's use of Japanese thanking routines. Díaz's study (2003) focused on the speech act of thanking from a pragmalinguistic viewpoint; he was interested in discovering the various modifiers which take part in the realization of this specific speech act in different contexts.

The study of attitudes towards languages is carried out from various disciplines that study human behaviour: Psychology, anthropology, sociology, etc. Moreno Fernández (1998: 182) discusses two linguistic theories from which we can study language attitudes: The conductist theory and the mentalist theory. Conductists understand the concept of attitude as behaviour, as a reaction or answer to a stimulus, whereas mentalists understand attitude as a mental state towards specific conditions and sociolinguistic facts. In this latter case, attitudes imply the presence of three elements that correspond with three components of the mentalist linguistic attitude: Value (affective component), knowledge or belief (cognitive component) and behaviour (connative component).

Our investigation follows the mentalist theory as we start from the assumption that non-native speakers of Spanish have some beliefs (cognitive component) with regards to the behaviour of native speakers of Spanish (connative component) in the development of the speech act of thanking in Spanish. This can lead non-native speakers of Spanish to generate a negative perception (affective component) about the language and culture and, as a consequence, about native speakers of Spanish. At the same time, thanking is also linked to the affective component of the linguistic attitude, as it shows emotions and feelings, from both individual speakers and a community of speakers.

In the area of research for the didactics of Spanish as a foreign language, and, in particular, in relation to the analysis and design of textbooks used for teaching and learning Spanish as a foreign language, Martín Peris (1996) examined textbooks published between 1979 and 1994, from both a methodological perspective and a teaching practice viewpoint. Areizaga Orube (1995) contrasted the methodological features of the textbooks with the evolution of language teaching and learning during the 70's and 80's. In her case, she used textbooks designed for teaching adult beginners in both U.S.A. and Spain. Ezeiza (2007) applied a computing tool in order to monitor the use of materials for teaching Spanish as a foreign language. His final aim was to establish a specific methodology that allows teachers and people responsible for designing study programmes, to audit the materials used for teaching Spanish as a foreign language. Miranda (2001) presented a contrastive analysis of teaching materials for both Spanish and English, both as foreign languages, and her main objective was to observe how politeness elements are presented in the textbooks from a pragmalingüistic point of view. In the same line of research, the study carried out by Rueda (1994) focused on the analysis of four textbooks by taking into consideration the guidelines from the Modern Languages for Communication document of the Department of State in the State of New York. Fernández López's work (2004) analysed some didactic materials used for teaching Spanish as a foreign language and proposed two materialanalysis questionnaires: One for the analysis of teaching methods and the other one for the analysis of textbooks.

To date, research work on thanking has focused, mainly on contrastive studies considering the development of thanking strategies from a linguistic viewpoint (from both meaning and function) according to the context in which the specific speech act is performed. Our study presents an innovative investigation as it explores the sociopragmatic elements of the speech act of thanking in order to discern the attitudes 
towards the Spanish language and culture of non-native speakers of Spanish. This has a clear implication for the materials used for teaching and learning Spanish as a foreign language. As a consequence, another aim of our study is to make teachers of Spanish as a foreign language aware of the necessity for learners to acquire an appropriate level of sociolinguistic and sociopragmatic competence in the target language.

\section{Methodology}

The first two groups of participants taking part in the study are 200 university students from English speaking countries (the U.K. and U.S.A.) who take Spanish as foreign language courses in both the UK and Spain, either as a university degree or as an optional subject, which is part of their study programme. The third group is formed by 100 Spanish native speakers from Spain who study Spanish and/or English as university degree programmes.

All participants are between 18 and 35 years old and were divided into three groups, according to their nationalities: British, American and Spanish. In this study the term 'American' always refers to those informants from the U.S.A., whilst the term 'Spanish' is used to refer to informants from Spain. In the case of American and British informants, we took into consideration their previous stay or residency in a Spanish speaking country as a possible intervening variable (see Appendix).

Data were collected by means of a questionnaire so that participants could show their attitude when faced with specific thanking situations. The data collection tool was designed following this procedure. Firstly, we extracted all the thanking dialogues found in the textbooks used for teaching and learning Spanish as a foreign language. We used a total of 64 textbooks, published between 1985 and 2006. The extraction of these dialogues was done taking into consideration two specific elements: The type of discourse (i.e. only oral) and the type of speech act (i.e. thanking). A selection was made of 250 dialogues from the textbooks which were then classified taking into consideration the general and specific classification criteria for thanking. The general classification was developed by taking into consideration the first two elements of the criteria established by Coulmas as shown in Table 1:

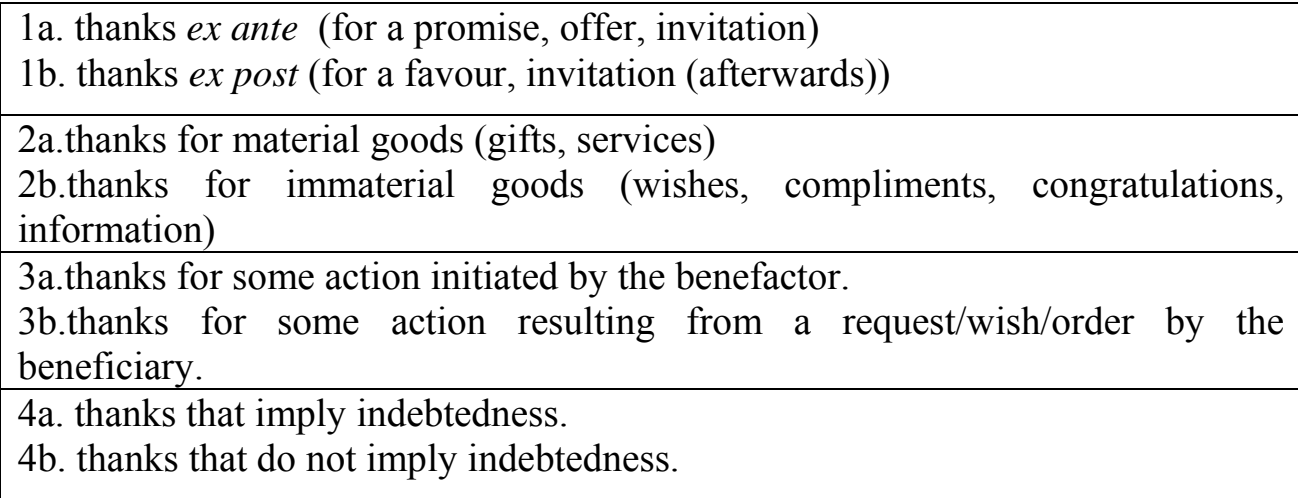

Table 1. Dimensions of the speech act of thanking. Coulmas (1981: 74) 
1. Thanking for offers or invitations.

1.1.1. Rejecting and offer

1.1.2. Accepting an offer.

1.1.3. Invitation (that has taken place or has not taken place/enjoyed or not enjoyed)

2. Thanking for receiving goods.

2.1.Non-material goods.

2.1.1. Receiving information previously requested.

2.1.2. Receiving good wishes and congratulations.

2.1.3. Receiving a compliment.

2.1.4. Receiving help and receiving permission.

2.2.Material goods.

2.2.1. Receiving objects and presents.

2.2.2. When borrowing objects.

3. Thanking for services rendered, performed actions and fulfilling requests.

3.1.Reaction or answer to a service rendered.

3.2.Reaction or answer to a performed action.

3.3.Fulfilling a request.

4. Thanking in ritual expressions ${ }^{1}$.

4.1.Answers to questions related to health or the state of things.

4.2. Answers to thanking.

Table 2. Proposal for the specific classification of the speech act of thanking.

We devised the specific classification of thanking, as shown in table 2, using the components which take part in this specific speech act (i.e. interlocutors, object of gratitude and type of action for which thanking is performed). The dialogues extracted from the textbooks were classified and quantified in order to create a questionnaire. The scenarios in the questionnaire were based on the most common situations found in dialogues in the textbooks.

The questionnaire (see Appendix) was written in English (for American and British participants) and in Spanish (for Spanish participants) as the main aim of the study was to discover the participants' attitudes towards the absence of thanking formulae. The questionnaire was organised into 12 different scenarios, as shown in Table 3, taking into consideration the relationship between the interlocutors, the type of object and the action for which thanking takes place.

1 This element of the classification refers to Goffman's hypothesis, included by Moreno Fernández (1986: 251) in his research on ritual expressions in a rural community. He explains that questions related to someone's health with a greeting intention, are answered by an adverbial form and thanking formulae. 


\begin{tabular}{|c|c|c|c|c|c|c|}
\hline Scenarios & 1 & 2 & 3 & 4 & 5 & 6 \\
\hline Interlocutor 1 & passer-by & $\begin{array}{l}\text { family } \\
\text { member }\end{array}$ & waiter & doctor & waiter & $\begin{array}{l}\text { shop } \\
\text { assistant }\end{array}$ \\
\hline Interlocutor 2 & passer-by & friend & client & patient & client & client \\
\hline Social distance & yes & yes & yes & no & yes & yes \\
\hline Social power & no & no & no & yes & no & no \\
\hline $\begin{array}{ll}\text { Object } & \text { for } \\
\text { thanking } & \\
\end{array}$ & $\begin{array}{l}\text { non } \\
\text { material }\end{array}$ & $\begin{array}{l}\text { non } \\
\text { material }\end{array}$ & material & $\begin{array}{l}\text { non } \\
\text { material }\end{array}$ & material & material \\
\hline Scenarios & 7 & 8 & 9 & 10 & 11 & 12 \\
\hline Interlocutor 1 & classmate & friend & friend & friend & student & classmate \\
\hline Interlocutor 2 & classmate & friend & friend & friend & student & classmate \\
\hline Social distance & no & no & no & no & no & no \\
\hline Social power & no & no & no & no & no & no \\
\hline $\begin{array}{ll}\text { Object } & \text { for } \\
\text { thanking } & \end{array}$ & $\begin{array}{l}\text { non } \\
\text { material }\end{array}$ & $\begin{array}{l}\text { non } \\
\text { material }\end{array}$ & material & material & $\begin{array}{l}\text { non } \\
\text { material }\end{array}$ & material \\
\hline
\end{tabular}

Table 3: Relationship between interlocutors and object of thanks. (material and non-material)

Each scenario of the questionnaire begins with a contextualization. Next, the complete verbal exchange is introduced as it was found in the textbooks, except for the omission of the thanking formula in the last intervention of the interlocutor. The thanking formula was omitted in order to ascertain the participants' reaction to the absence of this specific polite formula. At the end of each scenario, a series of questions or items related to the performance of the interlocutor in the last intervention are included. These refer to four different aspects: First, whether the final intervention of the speaker is appropriate or not (where participants consider that the answer is not appropriate, they are asked to provide an alternative answer); second, whether participants consider that the conversation could have taken place in the United States or the United Kingdom and in Spain; third, whether participants consider that the person in the final intervention is polite or impolite, considerate or inconsiderate; and finally, participants are also asked to show their degree of assuredness about the responses to all previous questions.

All questions included in each of the twelve scenarios of the questionnaire are answered by means of two different categories which represent both positive and negative aspects. Such categories are equivalent to quantitative values, from 1 to 5 of the Likert scale, which we then used to measure the linguistic attitudes. The following example corresponds with the first scenario of the questionnaire for the American participants:

At a metro station:

a. Excuse me, how do I get to Metropolitano? 
b. Well, you have to take line 4 towards Parque de Santa María until Avenida de América. There you need to change to line 6, the Circular one, and I think there are four or five stations to Metropolitano.

a. O.K.

Do you think that person A's final reply is appropriate?

$$
\text { NO } \quad 0 \quad 00000 \text { Y } 0 \text { Y }
$$

If not, what do you think s/he should have said?

How likely do you think this conversation would have been in the United States?

and in Spain?

not likely $\circ \quad \circ \quad 0 \quad 0 \quad 0 \quad$ very likely

not likely $\quad \circ \quad \circ \quad \circ \quad \circ \quad \circ \quad$ very likely

If person A was American, s/he would have been:

$\begin{array}{lllllll}\text { impolite } \circ & \circ & \circ & \circ & \circ & \text { polite } & \\ \text { thoughtless } & \circ & \circ & \circ & \circ & \circ & \text { thoughtful }\end{array}$

If person A was Spanish, s/he would have been:

$\begin{array}{lllllll}\text { impolite } \odot & \circ & \circ & \circ & \circ & \text { polite } & \\ \text { thoughtless } & \circ & \circ & \circ & \circ & \circ & \text { thoughtful }\end{array}$

How sure are you about your own answers?

$\begin{array}{lllllll}\text { NO } & 0 & 0 & 0 & 0 & 0 & \text { YES }\end{array}$

Each scenario in the questionnaire represents one of the most frequent uses of thanking situations found in the textbooks for teaching and learning Spanish as a foreign language. This is based on the specific classification of thanking, designed to categorize the dialogues found in the textbooks. The results of the questions, in which participants included an alternative answer, provided some findings on the specific uses of thanking in British, American and Spanish cultures. In this case, results were quantified according to the specific formulae suggested by participants. Data was analysed by contrasting the three independent variables of the study (nationality, gender and object of thanking) with the dependent variables (appropriate response, probability, politeness, thoughtfulness and assuredness) corresponding to the questions of each scenario. For the analysis of data, three types of statistical tests were used: The average, the standard deviation and the t-test.

\section{Results and discussion}

As shown in table 4, for every scenario of the questionnaire (where thanking was not performed), Spanish participants marked the highest level of probability, stating that those specific situations would take place in Spain. Therefore, Spanish native speakers clearly agree that not thanking is likely to happen in Spain. However, they also point out that the person in the dialogue is impolite and thoughtless. 


\begin{tabular}{|l|l|l|l|l|l|}
\hline & $\begin{array}{l}\text { appropriate } \\
\text { response }\end{array}$ & probability & politeness & thoughtfulness & assuredness \\
\hline $\begin{array}{l}\text { participants (USA) } \\
\text { average }\end{array}$ & 3.23 & 4.45 & 3.42 & 3.26 & 4.69 \\
standard deviation & 1.56 & 0.92 & 1.34 & 1.4 & 0.72 \\
\hline $\begin{array}{l}\text { participants } \\
\text { (Spain) }\end{array}$ & & & & & \\
$\begin{array}{l}\text { average } \\
\text { standard deviation }\end{array}$ & 3.3 & 4.46 & 3.45 & 3.3 & 4.71 \\
\hline $\begin{array}{l}\text { participants (UK) } \\
\text { average } \\
\text { standard deviation }\end{array}$ & 1.6 & 0.9 & 1.35 & 1.42 & 0.67 \\
\hline $\begin{array}{l}\mathrm{t} \text { test (USA - } \\
\text { Spain) }\end{array}$ & 1.47 & 3.62 & 3.46 & 3.46 & 3.44 \\
\hline $\mathrm{t}$ test (UK - Spain) & $\mathbf{0 . 0 0 0 2 2}$ & 0.96 & 1 & 1 & 1.14 \\
\hline $\mathrm{t}$ test (UK - USA) & $\mathbf{6 . 0 7 E - 0 6}$ & 0.17 & 0.14 & 0.23 & $\mathbf{5 . 9 8 E - 1 4 6}$ \\
\hline
\end{tabular}

Table 4. Contrastive analysis of the scenarios in the questionnaire.

When the interlocutor in the scenario is British, participants perceive the absence of the speech act thanking as an important element which shows lack of politeness. For the same group of British participants, the results present even more significant differences when the person not thanking is of Spanish nationality. Conversely, participants from the United States do not mark the absence of thanking as something impolite. However, results obtained from analysing data from male and female American participants do present these significant differences. American female participants indicated that a polite formula should have been included, in contrast with the results of the male participants.

Of the three groups of male participants, British men seemed to be the most concerned with the lack of politeness in the responses. However, Spanish male participants still indicated that the situations were very likely to happen in Spain and they also felt more assured about their answers than their British and American counterparts.

Results regarding the object of gratitude revealed significant differences between the groups of British and American participants. British participants marked the absence of gratitude as something important, regardless of the type of object (material or non-material objects). These types of differences were found to be less important between Spanish and American participants than the differences in perception between British and Spanish participants.

Between English native speakers, British participants marked the absence of thanking as being more significant than American participants; they believe that the speech act of thanking should have taken place in every scenario of the questionnaire.

Using the data found in this study, we can confirm Brown and Levinson's assertions ([1978] 1987) regarding positive and negative politeness cultures. We have found that the results position Spanish and American participants within positivepoliteness cultures, whereas the results for the British participants link them to negativepoliteness cultures. In more than half of the scenarios of the questionnaire we have seen differences, statistically proven, which allow us to confirm the existence of a discrepancy in approaches to thanking between the Spanish culture and British and 
American cultures. Both British and American speakers signal the absence of thanks in the Spanish culture as a remarkable fact and, as a consequence, they consider the Spanish as rude and inconsiderate when not thanking. However, we should indicate that the results of the group of American informants are similar, on occasion, to the group of Spanish informants.

The alternative answers provided due to the absence of the thanking formulae revealed interesting data for each scenario:

- In Spanish it seems necessary to use a polite expression not only when receiving a gift but also to add a remark related to it (see scenario 10 in Appendix). In this type of interaction, the sole use of the thanking speech act does not seem to be sufficient unless it is accompanied by the kind of remark that helps re-establish the possible threat to the negative face of the receiver of the gift. By contrast, in British and American cultures, the use of a thanking expression alone seems enough for this type of interaction.

- When answering commonplace questions, such as in a health situation (see scenario 8 in Appendix), it is not necessary to include a thanking formulae in Spanish, but questions are added that reflect interest for the health situation of the person who first asked. Interestingly, this is also the case in the American culture but not in the British, where it is necessary to express thanks.

- In Spanish it is not deemed necessary to use the thanking formulae in response to good wishes, when receiving a compliment and when being granted permission (see scenarios 7, 11 and 12 in Appendix). The social distance between the participants in these three situations and the type of object for which they are expected to thank are two key factors which determine the use of the speech act of thanking. In each of the three cases, there is no social distance between the speaker and the listener, and the object for which one is supposed to thank is non-material.

- Nor is it necessary in British and American cultures to express thanks when receiving good wishes or a compliment from someone. However, it is necessary to thank in Spanish when one receives information as a result of a previous petition and when one reacts or answers to a service rendered, for example, when shopping. The presence of thanking expressions in these two cases is directly dependent on the social distance that exists between the participants of both types of interaction. We then confirm Leech's remarks (1983: 10), that social distance is a factor directly linked to sociopragmatic principles and the usage variations associated with a language. The wider the social distance between participants, the higher the frequency of some specific formulae expressing politeness; in this case, thanking expressions.

- In British and American cultures, it is also necessary to thank when one reacts or answers to a service rendered, at a doctor's for example (see scenario 4 in Appendix), and when one reacts or answers to a performed action. The actions performed are reflected in the questionnaire by means of two situations: The first, passing a phone message on to an absent person and second (see scenario 2 in Appendix), a waiter bringing a bottle of wine in a restaurant (see scenario 3 in Appendix). We can confirm Hickey's (1991: 4) findings that thanking is not necessary because the word 'gracias' (thank you) in the Spanish culture tends to be literally used to thank for a personal favour, and not for services that are considered the normal attribution of a person in the performance of his/her job. 
- When accepting an offering (see scenario 9 in Appendix), the Spanish prefer to use request formulae (por favor, Spanish for please) instead of thanking formulae. The same happens, although less frequently, when declining an offering. It needs to be specified that the offerings refer to material objects in both cases. There is another extra linguistic factor, noted by Escandell (1996: 26), which determines the pragmalinguistic and sociopragmatic choice in a language. As in Spain, in British and American cultures, request formulae are also used when accepting an offering; however, in the British and American cultures, unlike the Spanish, the refusal of an offer tends to be related to thanking formulae exclusively, instead of request formulae. Following Brown and Levinson ([1978] 1987: 94), the act of offering can be considered a face threatening act (FTA) to the hearer; when offering, the sender intrudes into the receiver's personal space and, consequently, implies a threat to his negative face. In this situation, the FTA is done baldly, without any redress, as the offering is carried out in a direct and clear way. When declining an offering in Spanish, the receiver completes the negative answer with a request (No, por favor; Spanish for No, please). In this case, the receiver requires the sender not to perform the action related to the offering. However, in British and American cultures, when declining an offer, the receiver answers negatively but adds a thanking expression (no, gracias). This type of answer has the intention of minimising the imposition that the offering has on the receiver and, in its turn, of reinforcing the positive face of the receiver as he/she notices the action linked to the offering (unaccomplished by the sender) by means of the thanking. In British and American cultures, the action linked to the offering, which is not performed in a material way, is actually thanked for beforehand.

\section{Conclusion}

This research confirms our initial hypothesis about the negative attitudes that Englishspeakers (both British and American) have regarding the absence of the speech act of thanking in Spain. On the one hand, Spanish speakers accept, without any doubt, the fact that there is a very high probability of situations in which no thanks takes place in Spain, contrasting with the data collected from the British and Americans for each of the situations of the research questionnaire. On the other hand, the high degree of selfassuredness in the answers provided by the Spanish speakers differs clearly from the degree of self-assuredness in the answers given by the British and Americans. Consequently, the Spanish realise that those situations in which there is no thanking might be an integral part of the way of interacting in the Spanish culture, by contrast to what the British and the Americans indicate.

The information provided by the questionnaires has shown differences among the answers given by groups of men and groups of women. The only difference among men and women of the same nationality was found within the American group. However, the contrastive analyses among the groups of men and women (from all three nationalities) indicate differences, statistically shown, between the group of Spanish

men and that of the British and the Americans on one hand, and between the group of Spanish women with both British and American women on the other. Both Spanish men and women, unlike their British and American counterparts, indicate that the situations 
depicted in the scenarios of the questionnaire, in which thanking does not occur, are very likely to happen in Spain. The type of object which is a key element in the speech act of thanking is a determinant fact in the presence of this studied speech act. It is necessary to thank when the object is of a material nature, but not when the object is of a non-material nature.

The data obtained in the questionnaires completed by all native English-speakers establish significant differences between both groups of informants. Thanking in the British culture is a necessary speech act in certain contexts and, if absent, the British will consider it a sign of rudeness, showing a lack of consideration, thus producing a negative attitude. These results contrast with those provided by the English speakers of American nationality, as they seem not to have an attitude so negatively marked as the British

The design of the data collection questionnaire was based on the dialogues found in the textbooks used for teaching Spanish as a foreign language. The significant number of alternative responses provided by Spanish participants, which are different from thanking formulae, corroborate the fact that certain thanking situations, included in these textbooks, do not reflect Spanish socio-cultural reality.

From these conclusions we can confirm, in general terms, the possibility of a negative perception of sociocultural and interactional norms towards the Spanish culture in relation to the speech act of thanking by English-speakers (both British and American). This information should clearly be taken into account in the teaching of Spanish to English-speaking learners.

The findings of our research have also allowed us to confirm other phenomena of conversational characteristics that seem to be of great interest and could be examined as part of future investigations. Our study is a contrastive analysis of attitudes, taking the speech act of thanking as the focal point. Several research studies have been completed so far about the speech act of thanking from a pragmalinguistic point of view. Even so, we consider that further research can be carried out focused on the analysis of attitudes, but in relation to other types of speech acts such as apologising or requesting. These analyses can contrast Spanish and other languages with more distinctive sociopragmatic components than those we find in Western cultures. This is the case of languages such as Chinese, Japanese or Arabic. Further research directly related to the teaching of Spanish as a foreign language could also be carried out, such as the analysis of sociopragmatic acquisition starting from the immersion process in FL, in contrast to its acquisition in classroom settings.

\section{Acknowledgements}

I would like to thank my Ph.D. supervisor, Dr. Ana María Cestero Mancera, for her advice and guidance in this investigation. Thanks also to all the participants in the study from Universidad Antonio de Nebrija (Madrid), Universidad de Alcalá (Madrid) and University of East Anglia (UK). 


\section{References}

Aijmer, Karin (1996) Conversational Routines in English. Nueva York: Pearson Education.

Areizaga Orube, Elisabet (1995) Dos décadas de enseñanza del español como lengua extranjera a adultos en sus materiales. San Sebastián: Servicio editorial de la Universidad del País Vasco.

Aston, Guy (1995) Say Thank You: Some pragmatic constraints in conversational closings. Applied Linguistics 16: 57-86.

Blas Arroyo, Jose Luís (1994) Valencia y castellano. Actitudes lingüísticas en la sociedad valenciana. Estudio sobre una comunidad urbana. Hispania 77: 143-155.

Brown, Penelope, and Stephen C. Levinson (1987) [1978] Politeness. Some Universals in Language Use. Cambridge: Cambridge University Press.

Colston, Herbert L. (2002) Pragmatic justifications for nonliteral gratitude acknowledgements: Oh sure, any time. Metaphor and Symbol 17: 205-226.

Coulmas, Florian (1981) Poison to your soul: Thanks and apologies contrastively viewed. In F. Coulmas (ed.), Conversational Routine: Explorations in Standardized Communication Situations and Prepatterned Speech. The Netherlands: Mouton Publishers, pp. 69-91.

De Pablos-Ortega, Carlos (2009) Las actitudes lingüísticas de los anglohablantes ante el agradecimiento en Español: Enfoque sociopragmático. (unpublished doctoral thesis). Universidad de Nebrija, Spain.

Díaz Pérez, Francisco J. (2003) La cortesía verbal en inglés y en español. Actos de habla y pragmática intercultural. Jaén: Universidad de Jaén.

Dumitrescu, Domnita (2005) Una comparación entre la competencia pragmática de los estudiantes nativos y no nativos del español en California, Estados Unidos. In J. Murillo Medrano (ed.), Actas del Segundo Coloquio del Programa EDICE: Actos de habla y cortesía en distintas variedades del español: Perspectivas teóricas y metodológicas. Programa EDICE. www.edice.org, pp. 375-406.

Eisenstein, Miriam, and Jean W. Bodman (1986) I very appreciate': Expressions of gratitude by native and non-native speakers of American English. Applied Linguistics 7: 167-185.

Eelen, Gino (2001) A Critique of Politeness Theories. Manchester: St. Jerome.

Escandell Vidal, Maria V. (1996) Introducción a la pragmática. Barcelona: Ariel Lingüística.

Espí, María J., and Ma José Arzumendi (1996) Motivación, actitudes y aprendizaje del español como lengua extranjera. Revista española de lingüística aplicada 11: 63-76.

Ezeiza, Joseba (2007) Analizar y comprender la to pografía configuracional de los materiales de enseñanza de lenguas en una perspectiva de síntesis. (Unpublished doctoral thesis). Universidad de Nebrija.

Fernández López, Ma Carmen (2004) Principios y criterios para el análisis de materiales didácticos. In J. Sánchez Lobato and I. Santos Gargallo (eds.), Vademécum para la formación de profesores. Enseñar español como segunda lengua (L2)/lengua extranjera (LE). Madrid: S.G.E.L., pp. 715-734.

Ferrara, Kathleen (1994) Pragmatic transfer in American's use of Japanese thanking routines. Department of English (unpublished manuscript), University College Station, Texas.

Haverkate, Henk (1994) La cortesía verbal. Madrid: Gredos. 
Haverkate, Henk (2003) El análisis de la cortesía comunicativa: Caracterización pragmalingüística de la cultura española. In D. Bravo (ed.), Actas del Primer Coloquio del Programa EDICE: La perspectiva no etnocentrista de la cortesía: Identidad sociocultural de las comunidades hispanohablantes. Programa EDICE. www.edice.org, pp. 60-70.

Hickey, Leo (1991) Comparatively polite people in Spain and Britain. Association for Contemporary Iberian Studies Journal 4: 2-6.

Hickey, Leo (2005) Politeness in Spain: Thanks but no 'Thanks'. In L. Hickey y M. Stewart (eds.), Politeness in Europe. Clevendon: Multilingual Matters, pp. 317-330.

Huget-Canalís, Ángel (2001) Lenguas en contacto y educación: Influencia del prestigio de las lenguas en las actitudes lingüísticas de los escolares. Revista de educación, (Bilingüismo y Educación) 326: 355-371.

Hymes, Dell H. (1971) Sociolinguistics and ethnography of speaking. In E. Ardener (ed.), Social Anthropology and Language. London: Tavistock Publications, pp. 47-93.

Jacobsson, Mattias (2002) Thank you and thanks in Early Modern English. ICAME Journal 26: 63-80.

Kerbrat-Orecchioni, Catherine (2004) ¿Es universal la cortesía?. In D. Bravo and A. Briz (eds.), Pragmática sociocultural: Estudios sobre el discurso de cortesía en español. Barcelona: Ariel, pp. 39-54.

Kim, Y. (1994) Nihonjin jyakunensouno 'kansya' to 'wabi'no aisatsuno hyougenno anketo cyousa to sono kousatsu (A study of the expressions of gratitude and apology in Japanese young generation: In comparison with those in older generation) Kokugogaku Kenkyuu, The Japanese Language Review 33: 23-33.

Kimura, Kazumi (1994) The multiple functions of Sumimasen. Issues in Applied Linguistics 5: 279-302.

Kumatoridani, Tetsuo (1999) Alternation and co-occurrence in Japanese thanks. Journal of Pragmatics 31: 623-642.

Leech, Geoffrey N. (1983) Principles of pragmatics. London: Longman.

Martín Peris, Ernesto (1996) Las actividades de aprendizaje en los manuales de ELE. (Unpublished doctoral thesis). Universidad de Barcelona.

Martín Zorraquino, $\mathrm{M}^{\mathrm{a}}$ Antonia (1998) Sociolinguistic attitudes and beliefs towards dialectal and standard varieties in 'La Franja oriental de Aragón' (Spain). Folia Lingüística 33: 131-143.

Masgoret, Anne-Marie (2005) Examining the role of language attitudes and motivation on the sociocultural adjustment and the job performance of sojourners in Spain. International Journal of Intercultural Relations 30: 311-331.

Miranda, Horacio (2001) La cortesía verbal en los textos para la enseñanza del español e inglés como lenguas extranjeras. (Unpublished doctoral thesis) Universidad de Valladolid.

Miyake, Kazuo (1994) Wabi" igaide tsukawareru wabi hyogen: Sono tayoukatno jittaito uchi, soto, yosono kankei (Formulaic apologies in non-apologetic situations: A data analysis and its relation with the concept of uchi-soto-yoso). Nihongo Kyouiku (Journal of Japanese Language Teaching) 82: 134-146.

Moreno Fernández, Francisco (1986) Sociolingüística de los rituales de acceso en una comunidad rural. Lingüística Española Actual 8: 245-267.

Moreno Fernández, Francisco (1998) Principios de sociolingüística y sociología del lenguaje. Barcelona: Ariel Lingüística. 
Moriyama, T (1999) Oreito owabi: Kankei syufukuno sisutemu toshite (Gratitude and apologies: A system of repair), Kokubungaku: Kaishakuto kyouzaino kenkyu (Japanese Literature: Interpretation and Material development) 44: 78-82.

Nakada, Tomoko (1989) Hatsuwa kouitoshiteno chinshato kansha: Nichiei hikaku (Apology and thanks in Japanese and English), Nihongo Kyouiku (Journal of Japanese Language Teaching) 68: 191-203.

Ogawa, Haruko (1995) Kansha to wabino teishiki hyougen: Bogowashano shiyou jitttaino cyousa karano bunseki (A Study of Japanese formulaic thanks and apologies: A data analysis of the use by Japanese native speakers), Nihongo Kyouiku (Journal of Japanese Language Teaching) 85: 38-52.

Ortega, Gonzalo D. (1981) El español hablado en Canarias: Visión sociolingüística. Revista de Filología de la Universidad de La Laguna 0: 111-115.

Rueda Bernao, Ma José (1994) Análisis de cuatro manuales para la enseñanza del español, lengua extranjera. In Actas del IV Congreso Internacional de ASELE: Problemas y Métodos en la Enseñanza del Español como Lengua Extranjera. Madrid: Centro Virtual Cervantes. www.cvc.cervante.es, pp. 195-203

Searle, John R. (1976) A classification of illocutionary acts. Language and Society 5: 1-23.

Thomas, Jenny (1983) Cross-cultural pragmatic failure. Applied Linguistics 4: 91-112.

Urrutia, Hernán (1999) Bilingüismo y rendimiento académico en la Comunidad Autónoma Vasca (CAV). In J.A. Samper and M. Troya (eds.), Actas del XI Congreso Internacional de la Asociación de Lingüística y Filología de la América Latina. Las Palmas de Gran Canaria, pp. 1311-1324.

Villamil, Asunción (2002) Gallegos en Madrid: Actitudes y mantenimiento de la lengua gallega. Madrygal. Revista de estudios Gallegos 7: 123-132.

Watts, Richard (2003) Politeness. Cambridge: Cambridge University Press.

\section{Appendix: Questionnaire (American participants)}

Name (optional):

Informant number: (please do not fill this out)

Please answer the following questions before you take part in the study.

1. Date of birth:

2. Nationality:

3. Country of residence:

4. University/Study Program:

5. How long have you been studying Spanish?

(In years and months, please) ___ yrs____ months

6. Have you ever lived in a Spanish speaking country before?

$\square$ No, this is my first time. $\quad \square$ Yes

If yes: Where?

How long? (In years and months, please) ___ yrs months

7. Do you have any certificate in Spanish? Yes $\square$

If yes, please specify:

PLEASE READ THE FOLLOWING SITUATIONS CAREFULLY AND COMPLETE THE QUESTIONNAIRE BELOW. BE AS SINCERE AS POSSIBLE:

Scenario 1

At a metro station:

c. Excuse me, how do I get to Metropolitano? 
d. Well, you have to take line 4 towards Parque de Santa María until Avenida de América. There you need to change to line 6, the Circular one, and I think there are four or five stations to Metropolitano.

b. O.K.

Do you think that person A's final reply is appropriate?

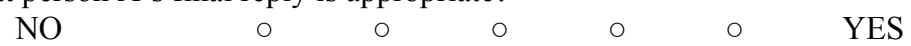

If not, what do you think s/he should have said?

How likely do you think this conversation would have been in the United States?

and in Spain?

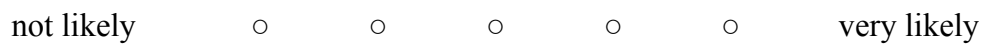

not likely $\quad \circ \quad \circ \quad \circ \quad \circ \quad \circ \quad$ very likely

If person A was American, s/he would have been:

$\begin{array}{llllll}\text { impolite } \quad \circ \quad 0 & 0 & 0 & 0 & \text { polite }\end{array}$

$\begin{array}{llllll}\text { thoughtless } \quad \circ & 0 & 0 & 0 & \circ & \text { thoughtful }\end{array}$

If person A was Spanish, s/he would have been:

$\begin{array}{lllllll}\text { impolite } & \circ & \circ & 0 & \circ & \circ & \text { polite } \\ \text { thoughtless } & \circ & \circ & \circ & \circ & \circ & \text { thoughtful }\end{array}$

How sure are you about your own answers?

$\mathrm{NO}$

$0 \quad 0$

$\circ \quad 0 \quad 0 \quad$ YES

Scenario 2

A telephone conversation:

a. Is Maria in?

b. No, she is not at the moment

a. Do you know what time she'll be back?

b. Well, I don't really know. She didn't tell me.

a. Well. This is Sam. I'll call her back before nine.

Do you think that person A's final reply is appropriate?
NO

$\circ$
$\mathrm{d}$ have said?

If not, what do you think s/he should have said?

How likely do you think this conversation would have been in the United States?

and in Spain?

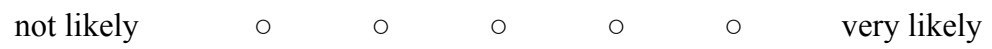

$\begin{array}{llllll}\text { not likely } \quad \circ & 0 & 0 & \circ & \circ & \text { very likely }\end{array}$

If person A was American, s/he would have been:

$\begin{array}{llllll}\text { impolite } & 0 & 0 & 0 & 0 & 0\end{array}$

$\begin{array}{llllll}\text { thoughtless } \quad \circ & 0 & 0 & 0 & 0 & \text { thoughtful }\end{array}$

If person A was Spanish, s/he would have been:

$\begin{array}{lllllll}\text { impolite } & \circ & \circ & \circ & \circ & \circ & \text { polite } \\ \text { thoughtless } & \circ & \circ & \circ & \circ & \circ & \text { thoughtful }\end{array}$

How sure are you about your own answers?

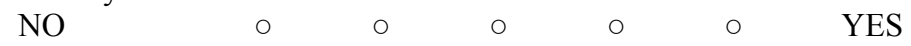

$\underline{\text { Scenario } 3}$

In a restaurant:

Bartender: And what would you like to drink?

a.: Bring us a red wine. A "reserve".

Bartender: A house wine?

a.: Yes.

Do you think that person A's final reply is appropriate?

$\begin{array}{llllll}\text { NO } & 0 & 0 & 0 & 0 & 0\end{array}$

If not, what do you think s/he should have said?

How likely do you think this conversation would have been in the United States?
not likely
$\circ \quad 0$
$\circ \quad 0$
$\circ \quad 0$
very likely 
and in Spain?

not likely $\quad \circ \quad \circ \quad \circ \quad \circ \quad \circ \quad$ very likely

If person A was American, s/he would have been:

$\begin{array}{llllll}\text { impolite } \quad \circ & 0 & 0 & 0 & \circ & \text { polite }\end{array}$

$\begin{array}{lllllll}\text { thoughtless } & 0 & 0 & 0 & 0 & 0 & \text { thoughtful }\end{array}$

If person A was Spanish, s/he would have been:

$\begin{array}{lcccccl}\text { impolite } & \circ & \circ & \circ & \circ & \circ & \text { polite } \\ \text { thoughtless } & \circ & \circ & \circ & \circ & \circ & \text { thoughtful }\end{array}$

How sure are you about your own answers?

$\begin{array}{lllllll}\text { NO } & 0 & 0 & 0 & 0 & 0 & \text { YES }\end{array}$

Scenario 4

At a doctor's office:

a. First I am going to take your blood pressure and I am going to prescribe you some cream for your back and some tablets. Anyway, you shouldn't worry.

b. Shall I come back again next week?

a. Yes. Once the test results are ready, I'll call/inform you.

b. See you, doctor!

Do you think that person B's final reply is appropriate?
$\mathrm{NO}$
$0 \quad 0$
o
$\circ \quad 0 \quad$ YES

If not, what do you think s/he should have said?

How likely do you think this conversation would have been in the United States?

and in Spain?

not likely $\quad \circ \quad \circ \quad \circ \quad \circ \quad \circ \quad$ very likely

$\begin{array}{lllllll}\text { not likely } \quad \circ & \circ & \circ & \circ & \circ & \text { very likely }\end{array}$

If person B was American, s/he would have been:

$\begin{array}{lllllll}\text { impolite } & \circ & 0 & \circ & 0 & \circ & \text { polite } \\ \text { thoughtless } & \circ & \circ & \circ & \circ & \circ & \text { thoughtful }\end{array}$

If person B was Spanish, s/he would have been:

$\begin{array}{lllllll}\text { impolite } & \circ & \circ & 0 & \circ & \circ & \text { polite } \\ \text { thoughtless } & \circ & \circ & \circ & \circ & \circ & \text { thoughtful }\end{array}$

How sure are you about your own answers?

$\underline{\text { Scenario } 5}$

$\begin{array}{llllll}\text { NO } & 0 & 0 & 0 & \circ & \text { YES }\end{array}$

In a bar:

a. Hi! What would you like?

b. A ham sandwich, please.

a. With cheese?

b. No.

Do you think that person B's final reply is appropriate?
NO

$\circ \quad \circ$

If not, what do you think s/he should have said?

How likely do you think this conversation would have been in the United States?

\begin{tabular}{|c|c|c|c|c|c|c|c|}
\hline \multicolumn{8}{|l|}{ and in Spain? } \\
\hline & not likely & 0 & 0 & 0 & 0 & 0 & very likely \\
\hline \multicolumn{8}{|c|}{ If person B was American, s/he would have been: } \\
\hline & impolite & ○ & $\circ$ & 0 & ○ & $\circ$ & \multirow{2}{*}{$\begin{array}{l}\text { polite } \\
\text { thoughtful }\end{array}$} \\
\hline & thoughtless & ○ & $\circ$ & ○ & ○ & $\circ$ & \\
\hline \multicolumn{8}{|c|}{ If person B was Spanish, s/he would have been: } \\
\hline & impolite & ○ & ○ & ○ & ० & o & \multirow{2}{*}{$\begin{array}{l}\text { polite } \\
\text { thoughtful }\end{array}$} \\
\hline & thoughtless & ○ & ○ & ○ & ○ & $\circ$ & \\
\hline
\end{tabular}

How sure are you about your own answers?
$\mathrm{NO}$
$0 \quad 0$
$\circ \quad 0$
$\circ$
YES 
Scenario 6

At a clothes store:

Store assistant: Good morning. Can I help you?

a: Yes. I would like some pants.

Store assistant: Which size?

a: Well, I don't know... 13 or 14, I think.

Store assistant: In those sizes we have them in grey, blue and black. Which ones would you like?

a: These blue are fine. Can I try them on?

Store assistant: Yes, of course. The changing room is over there.

(After trying them on)

Store assistant: How do they look?

a: They fit me well. I will take them. How much are they?

Store assistant: They are reduced. They only cost $58 €$. How would you like to pay? Cash or credit card?

a: By card.

Store assistant: Here you are.

a.: Bye.

Do you think that person A's final reply is appropriate?

$\begin{array}{lcccccc}\text { NO } & 0 & 0 & 0 & 0 & \circ & \text { YES }\end{array}$

If not, what do you think s/he should have said?

How likely do you think this conversation would have been in the United States?

\begin{tabular}{|c|c|c|c|c|c|c|c|}
\hline \multicolumn{8}{|l|}{ and in Spain? } \\
\hline & not likely & o & 0 & o & 0 & o & very likely \\
\hline \multicolumn{8}{|c|}{ If person A was American, s/he would have been: } \\
\hline & impolite & 0 & 0 & o & 0 & o & \multirow{2}{*}{$\begin{array}{l}\text { polite } \\
\text { thoughtful }\end{array}$} \\
\hline & thoughtless & o & ० & o & o & o & \\
\hline \multicolumn{8}{|c|}{ If person A was Spanish, s/he would have been: } \\
\hline & impolite & 0 & 0 & o & 0 & o & \multirow{2}{*}{$\begin{array}{l}\text { polite } \\
\text { thoughtful }\end{array}$} \\
\hline & thoughtless & 0 & o & 0 & 0 & o & \\
\hline
\end{tabular}

How sure are you about your own answers?

$\underline{\text { Scenario } 7}$

$\begin{array}{llllll}\text { NO } & 0 & 0 & 0 & \circ & \text { YES }\end{array}$

After class at the University:

a. Are you coming for a drink?

b. No, I can't. I've got a job interview.

a. Good luck!

b. Enjoy your drink!

Do you think that person B's final reply is appropriate?
NO
$0 \quad 0$

If not, what do you think s/he should have said?

How likely do you think this conversation would have been in the United States?

\begin{tabular}{|c|c|c|c|c|c|c|c|}
\hline \multirow{2}{*}{ and in Spain? } & not likely & 0 & 0 & 0 & 0 & 0 & very likely \\
\hline \multirow{2}{*}{\multicolumn{8}{|c|}{$\begin{array}{ccc}\text { not likely } & \circ & \circ \\
\text { If person B was American, } \mathrm{s} / \text { he would have been: }\end{array}$}} \\
\hline & & & & & & & \\
\hline & impolite & ○ & ○ & ○ & ० & $\circ$ & \multirow{2}{*}{$\begin{array}{l}\text { polite } \\
\text { thoughtful }\end{array}$} \\
\hline & thoughtless & ○ & ○ & ○ & o & o & \\
\hline \multicolumn{8}{|c|}{ If person B was Spanish, s/he would have been: } \\
\hline & impolite & ○ & o & 0 & 0 & 0 & \multirow{2}{*}{$\begin{array}{l}\text { polite } \\
\text { thoughtful }\end{array}$} \\
\hline & thoughtless & o & 0 & o & o & o & \\
\hline
\end{tabular}

How sure are you about your own answers?

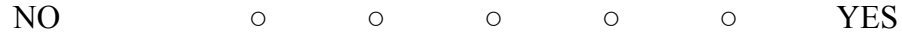


$\underline{\text { Scenario } 8}$

In the street:

a. Manuel! How long has it been? How is everything going?

b. Fine, fine, I can't complain. And how are you?

a. Well, not too bad...

b. And your family?

a. Fine.

Do you think that person A's final reply is appropriate?

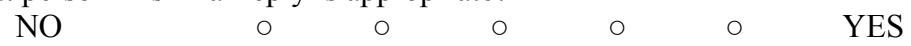

If not, what do you think s/he should have said?

How likely do you think this conversation would have been in the United States?

\begin{tabular}{|c|c|c|c|c|c|c|}
\hline \multicolumn{7}{|l|}{ and in Spain? } \\
\hline not likely & 0 & 0 & 0 & 0 & 0 & very like \\
\hline \multicolumn{7}{|c|}{ If person A was American, s/he would have been: } \\
\hline impolite & 0 & o & ○ & o & o & \multirow{2}{*}{$\begin{array}{l}\text { polite } \\
\text { thoughtful }\end{array}$} \\
\hline thoughtless & ○ & ○ & ○ & ○ & o & \\
\hline \multicolumn{7}{|c|}{ If person A was Spanish, s/he would have been: } \\
\hline impolite & o & o & o & o & o & \multirow{2}{*}{$\begin{array}{l}\text { polite } \\
\text { thoughtful }\end{array}$} \\
\hline thoughtless & ○ & o & o & ○ & o & \\
\hline \multicolumn{7}{|c|}{ How sure are you about your own answers? } \\
\hline NO & 0 & o & o & o & o & YES \\
\hline
\end{tabular}

$\underline{\text { Scenario } 9}$

In the lounge in your house:

a. Excuse me. Would you mind passing me that magazine?

b. Yes, here you are. Do you want me to put the light on?

a. Yes.

Do you think that person A's final reply is appropriate?

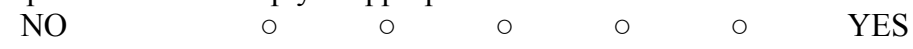

If not, what do you think s/he should have said?

How likely do you think this conversation would have been in the United States?

and in Spain?

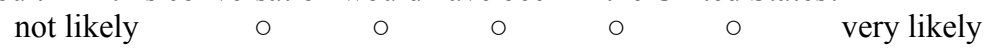

not likely $\quad \circ \quad \circ \quad \circ \quad \circ \quad \circ \quad$ very likely

If person A was American, s/he would have been:

impolite $\circ \quad \circ \quad \circ \quad \circ \quad \circ$ polite

$\begin{array}{llllll}\text { thoughtless } \circ & \circ & 0 & 0 & \circ & \text { thoughtful }\end{array}$

If person A was Spanish, s/he would have been:

$\begin{array}{llllll}\text { impolite } & \circ & 0 & 0 & 0 & \circ\end{array}$

$\begin{array}{llllll}\text { thoughtless } \quad \circ \quad \circ \quad \circ \quad 0 & \text { thoughtful }\end{array}$

How sure are you about your own answers?

NO 0 O $\quad 0 \quad 0 \quad 0 \quad$ YES

Scenario 10

At a birthday party:

a. Happy birthday! What a lot of flowers! The birthday cards are very nice. Here is your present.

b. (While opening the present) It's a very big packet! (He/she opens it and it's a sweater) It's very nice. I like it very much.

a. We hope it fits you.

b. Yes, It will. I am very happy.

Do you think that person B's final reply is appropriate? 


$\begin{array}{llllll}\text { NO } & 0 & 0 & 0 & 0 & \text { YES }\end{array}$

If not, what do you think s/he should have said?

How likely do you think this conversation would have been in the United States?

\begin{tabular}{|c|c|c|c|c|c|c|}
\hline \multicolumn{7}{|l|}{ and in Spain? } \\
\hline not likely & 0 & 0 & 0 & 0 & 0 & very likely \\
\hline \multicolumn{7}{|c|}{ If person B was American, s/he would have been: } \\
\hline impolite & o & $\circ$ & ○ & o & o & \multirow{2}{*}{$\begin{array}{l}\text { polite } \\
\text { thoughtful }\end{array}$} \\
\hline thoughtless & o & $\circ$ & o & o & o & \\
\hline \multicolumn{7}{|c|}{ If person B was Spanish, s/he would have been: } \\
\hline impolite & o & ○ & o & o & o & \multirow{2}{*}{$\begin{array}{l}\text { polite } \\
\text { thoughtful }\end{array}$} \\
\hline thoughtless & o & o & o & ○ & o & \\
\hline \multicolumn{7}{|c|}{ How sure are you about your own answers? } \\
\hline NO & 0 & ○ & 0 & o & o & YES \\
\hline
\end{tabular}

Scenario 11

A conversation with a foreign student:

a. How long have you been in Spain?

b. Six months

a. Really? You speak Spanish very well!

b. I started learning Spanish two years ago, in my country.

Do you think that person B's final reply is appropriate?

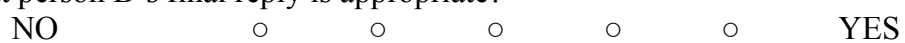

If not, what do you think s/he should have said?

How likely do you think this conversation would have been in the United States?

and in Spain?

not likely $\quad \circ \quad \circ \quad \circ \quad \circ \quad \circ \quad$ very likely
not likely
$\circ \quad 0$
$\circ \quad 0$
$\circ$
very likely

If person B was American, s/he would have been:

$\begin{array}{lllllll}\text { impolite } & \circ & \circ & \circ & \circ & \circ & \text { polite } \\ \text { thoughtless } & \circ & \circ & \circ & \circ & \circ & \text { thoughtful }\end{array}$

If person B was Spanish, s/he would have been:

$\begin{array}{lllllll}\text { impolite } & \circ & \circ & \circ & \circ & \circ & \text { polite } \\ \text { thoughtless } & \circ & \circ & \circ & \circ & \circ & \text { thoughtful }\end{array}$

How sure are you about your own answers?

$\begin{array}{lllllll}\text { NO } & 0 & 0 & 0 & 0 & 0 & \text { YES }\end{array}$

$\underline{\text { Scenario } 12}$

In a classroom at the University:

a. Excuse me. Can I open the window?

b. Of course. Open it, open it.

a. The heating is too high.

b. No, go ahead. It's no problem.

a. O.K

Do you think that person A's final reply is appropriate?

$\begin{array}{lllllll}\text { NO } & 0 & 0 & 0 & 0 & 0 & \text { YES }\end{array}$

If not, what do you think s/he should have said?

How likely do you think this conversation would have been in the United States? and in Spain? not likely $\circ \quad \circ \quad \circ \quad \circ \quad \circ \quad$ very likely not likely $\quad \circ \quad \circ \quad \circ \quad \circ \quad \circ \quad$ very likely

If person A was American, s/he would have been: 


\begin{tabular}{|c|c|c|c|c|c|c|}
\hline impolite & 0 & 0 & 0 & 0 & 0 & polite \\
\hline thoughtless & 0 & 0 & 0 & 0 & 0 & thoughtful \\
\hline \multicolumn{7}{|c|}{ Spanish, s/he would have been: } \\
\hline impolite & ○ & ○ & 0 & O & 0 & polite \\
\hline thoughtless & o & ○ & 0 & o & ○ & thoughtful \\
\hline \multicolumn{7}{|c|}{ u about your own answers? } \\
\hline NO & 0 & 0 & 0 & 0 & 0 & YES \\
\hline
\end{tabular}

\section{Appendix : List of abbreviations used}

FTA Face threatening act

FL Foreign language

CARLOS DE PABLOS-ORTEGA is a Lecturer in the School of Language and Communication Studies at the University of East Anglia, Norwich, UK. He earned his Ph.D. in Applied Linguistics from the University Antonio de Nebrija in Madrid, Spain, in July 2009. His doctoral dissertation focused on the attitudes of English native speakers towards the speech act of thanking in Spanish from a sociopragmatic point of view. He studies intercultural communication through audio-visual translation, in particular, the translation of specific speech acts in audiovisual resources in relation to cultural representations and stereotypes.

Address: Head of Spanish, School of Language and Communication Studies, University of East Anglia, United Kingdom. Tel.: 44-01603-593354; e-mail: c.de-pablos@uea.ac.uk 